Essay

\title{
NORM THEORY AND THE FUTURE OF THE FEDERAL APPOINTMENTS PROCESS
}

\author{
MICHAEL J. GERHARDT $\dagger$
}

\section{INTRODUCTION}

The way George W. Bush became the forty-third President of the United States was extraordinary in ways that we are still assessing. ${ }^{1}$ In addition to Bush's contested presidential victory, the election produced an unprecedented 50-50 split in the Senate, with Vice President Richard Cheney able to cast a tie-breaking vote. Because many Senate votes on presidential appointments are likely to be close, ${ }^{2}$ George $\mathrm{W}$. Bush's presidency provides a unique setting for testing the robustness of appointments norms: the behavioral regularities of presidents and senators regarding appointments that persist in the absence of formal rules and that deviations from which trigger sanctions. ${ }^{3}$

Copyright $@ 2001$ by Michael J. Gerhardt.

$\dagger$ Arthur B. Hanson Professor of Law, William \& Mary Law School. I am grateful to Jack Balkin, Erwin Chemerinsky, Michael Dorf, Chris Eisgruber, Deborah Gerhardt, Paul Schwartz, and David Strauss for helpful discussions regarding the subject of this Essay.

1. These circumstances are well known: George W. Bush became President after winning a majority of the Electoral College by the second-smallest margin in American history. Bush is also the first person in over 100 years to have won the presidency despite having lost the popular vote. Moreover, Bush became President after an intense, postelection contest over Florida's electors, a contest ultimately settled by the Supreme Court's controversial 5-4 decision in Bush v. Gore, 121 S. Ct. 525 (2000).

2. The fifty-fifty split in the Senate raised the possibility that any defection in either party on a vote or in party membership would significantly affect the appointments process. In fact, Vermont Senator James Jeffords' decision to leave the Republican party and to become an independent shifted control of the Senate back to the Democrats. Alison Mitchell, G.O.P. Senator Plans Shift, Giving Democrats Control in Setback for White House, N.Y. TIMES, May 24, 2001, at A1. Jeffords' switch ensures trouble for Bush appointments. Even before they took control of the Senate, Democratic senators had signaled to President Bush that they had already been preparing for pitched battles over judicial nominations, which are traditionally given the least deference of any category of presidential nomination. See infra note 70 and accompanying text.

3. Norm theorists tend to focus predominantly on social norms, though they generally disagree over the definition, range, origins, and the reasons for the fluctuations or evolution of 
In this Essay, I examine national political leaders' prospects for taking advantage of existing appointments norms or inventing new ones. ${ }^{4}$ Using examples from the presidencies of Bill Clinton and George W. Bush, I argue that national political leaders' compliance with and manipulation of norms can facilitate the fulfillment of personal or party agendas on federal appointments. While the constitutional structure and Senate rules governing appointments generally are resistant to formal alteration, the same is not true of the institutional norms governing appointments. The fact that some appointments norms are in flux raises the possibility that they are more amenable to change than the formal structure and rules of the appointments process, which change only under extraordinary circumstances. ${ }^{5}$ Appreciating the nature of flux in appointments norms is crucial for determining how norms can be managed to achieve certain results in, and, possibly, to achieve reform of, the appointments process.

To appreciate the nature and significance of the flux in appointments norms, one needs initially to understand the range of appointments norms. While many appointments norms have been discussed

such norms. Nevertheless, social norms are commonly understood as behavioral regularities among private actors that persist in the absence of formal rules and that trigger expressions of disapproval or sanctions when deviated from. See, e.g., ERIC A. Posner, LAW AND Social NORMS 7-8 (2000) ("What distinguishes social norms from other behavioral regularities is that departure from them provokes sanction."); Russell B. Korobkin \& Thomas S. Ulen, Law and Behavioral Science: Removing the Rationality Assumption from Law and Economics, 88 CAL. L. REV. 1051, 1127 (2000) (defining social norms "as social attitudes that specify what behaviors an actor ought to exhibit"). Norm theorists recognize at least three kinds of social norms-rationality-limiting, preference-changing, and equilibrium-selection norms. Kaushik Basu, Social Norms and the Law, in 3 THE NeW PALGRAVE DictionARY OF ECONOMICS AND THE LAW 476, 476-77 (Peter Newman ed., 1998). In contrast to social norms, institutional norms operate within and sometimes between various institutions. In this Essay, my focus is on such norms. One interesting question, not yet studied in detail by norm theorists, is how institutional norms relate to social norms. My sense is that social norms define a relatively large realm of activity, one possible subcategory of which may be institutional norms. Within this subcategory is a subset that involves the behavioral regularities of the leaders of national political institutions developed within the loose constitutional framework of checks and balances to constrain or guide their interaction over shared areas of responsibility, including, but not limited to, appointments matters.

4. My analysis begins where my book, Michael J. Gerhardt, ThE Federal Appointments Process: A Constitutional AND Historical ANALYsis (2000), ended. A basic thesis of the book is that appointments norms can be inferred from the patterns and practices of presidents and senators throughout American history. These institutional norms are the same as those operating generally in the legislative process. Whereas the book focused on the patterns and practices of official activity regarding appointments throughout American history, the focus of this Essay is prospective.

5. See infra notes $38-42$ and accompanying text. 
elsewhere, ${ }^{6}$ Section I clarifies the application of such norms to subcabinet appointments. Various factors combine to produce more Senate contests over subcabinet than cabinet nominations. These factors include the comparatively large numbers of subcabinet offices; the narrower jurisdiction of such offices, allowing their occupants to exercise direct responsibility over ideological battlefields such as civil rights; the greater vulnerability of subcabinet nominations to logrolling; propensities toward party-line voting; and Senate rules allowing subcabinet appointments to be thwarted more easily than cabinet ones.

Moreover, I examine two recent consequences of uncertainty about which norms govern. The first involves "norm ambiguity," or the potential for development of a new norm when there is conflict over the meaning of an existing norm. ${ }^{7}$ An example of such conflict concerns recent uncertainty about whether sitting U.S. Attorneys should tender resignations at the outset of new presidential administrations. ${ }^{8}$ The second consists of responses to the absence of clearly governing norms, which invites actors to protect or expand their authority. A recent illustration is the tendency of presidents interested in consolidating control over policymaking to increase the number and responsibility of staff members who are not subject to Senate confirmation. ${ }^{9}$

In Section II, I explore the relevance of norm theory to reform of the appointments process. First, complying with certain norms (such as senatorial courtesy ${ }^{10}$ and the use of moderate rhetoric to create a framing effect that lowers expectations) can break logjams in judicial confirmations. Second, appreciating the significance of rhetoric and

6. See, e.g., GERHARDT, supra note 4, at 162-74, 301-14 (reviewing various patterns and practices in the confirmation process and analyzing judicial selection norms); Brannon P. Denning, Reforming the Confirmation Process: Replacing "Despise and Resent" with "Advice and Consent," 53 ADMIN. L. REV. 1, 14-25 (2001) (reviewing the rise and fall of various norms applicable to federal appointments).

7. See infra note 29 and accompanying text.

8. See infra notes 29-34 and accompanying text.

9. See infra notes 35-37 and accompanying text.

10. "Senatorial courtesy" has three possible meanings. First, it can refer to senators' expectations that presidents (from the same party) will defer to their preferred choices to fill federal offices in their respective states. GERHARDT, supra note 4, at 143. Second, it can refer to senators' deference to nominations of members of Congress, particularly other senators, to offices that require confirmation. Id. at 143-44. Third, it can refer to presidents' deference to some senators' suggested nominations to offices in which they have special interest or expertise. Id. at 144. 
norms in confirmation contests is essential for evaluating whether some reforms of the confirmation process, such as limiting the questioning of judicial nominees, are feasible. Third, the success of political leaders as norm entrepreneurs depends less on their personal attributes $^{11}$ than on their manipulation of resources, including their political support, to withstand retaliation for attempted innovations and expansions of institutional prerogatives.

\section{THE NORMS OF POLITICAL APPOINTMENTS}

If there is any confusion about the norms applicable to different types of appointments, it likely pertains to the deference Congress gives the President's political appointments. This section seeks to eliminate this confusion. First, I explain the factors affecting how certain institutional norms apply to different kinds of appointments. Second, I examine the implications of conflict or uncertainty over applicable norms for subcabinet appointments.

\section{A. Factors Influencing Senate Contests over Political Appointments}

While senators claim to defer generally to both the President's cabinet and subcabinet nominations, there are subtle but significant differences in the institutional norms governing these two kinds of nominations. To understand these differences, some clarification of the nature of Senate deference to cabinet nominees is in order. In all of American history, the Senate has rejected only eight cabinet nominations. ${ }^{12}$ The rarity of cabinet nominees' formal rejection reflects

11. I disagree with the noted norm theorist, Eric Posner, who suggests that political leaders who act as norm entrepreneurs undertake the necessary risks involved with violating existing norms because of certain personal traits. POSNER, supra note 3, at 32. I suggest political leaders can be successful norm entrepreneurs when they preserve or expand institutional prerogatives by means of manipulating or mobilizing core constituencies or political resources. See infra notes 84-103 and accompanying text.

12. The eight rejected nominees were Roger Taney, as President Jackson's Treasury Secretary; Caleb Cushing, as President Tyler's Treasury Secretary; James Green, as President Tyler's Treasury Secretary; James Porter, as President Tyler's Secretary of War; Henry Stanbery, as Andrew Johnson's Attorney General; Charles Warren, as President Coolidge's Attorney General; Lewis Strauss, as President Eisenhower's Commerce Secretary; and John Tower, as President George H.W. Bush's Defense Secretary. GERHARDT, supra note 4, at 105-06, 164-65. In my opinion, one theme that conceivably links all of these rejections, with the possible exception of Senator Tower's nomination as Defense Secretary, is that each implicated a controversial or sensitive policy or constitutional issue. See id. at 105 ("The federal appointments process is a popular forum for senators who disapprove of or dislike a president or some of his policies."). But see id. at 164 (suggesting the reasons for some of these rejections were "largely personal"). Tower's nomination ran into serious difficulties because of personal misconduct including wom- 
senators' recognition that cabinet officials will work very closely with the President. ${ }^{13}$ They also will be closely identified with the President who appointed them. Deference to these nominations allows the President to choose the people on whom he wishes to rely to implement his policy preferences. Cabinet officers report directly to the President and operate directly under his supervision. Also, because presidents are held accountable for the laudable or controversial policies of their cabinet officers, senators generally give presidents broad discretion in choosing them. ${ }^{14}$

anizing and drinking. See, e.g., William G. Ross, The Senate's Constitutional Role in Confirming Cabinet Nominees and Other Executive Officers, 48 SYRACUSE L. REV. 1123, 1160-61 (1998) (discussing the Senate Committee on Armed Services' "deliberations on Tower's sex life and his drinking habits," which resulted in the Committee's unfavorable report on Tower's nomination). These difficulties became fatal in part because of some senators' concerns that confirming Tower would send the wrong signal to the military or risk injuring the morale of service personnel who are expected to refrain from, and will be punished, if not driven from the service, for, similar misbehavior. See, e.g., id. at 1161 ("The majority [on the Committee] . . . emphasized that a Secretary of Defense also should adhere to a high standard of sobriety and sexual decorum that would serve as a model for military personnel and civilian defense employees.").

13. See, e.g., 123 Cong. Rec. S2294 (1977) (statement of Sen. Percy) (the President "should be allowed to have as his closest advisors and policy managers those with whose expertise in a given field he is most comfortable and whose leadership of their Department would most reflect the President's priorities"); 105 CONG. REC. S9995 (1959) (statement of Sen. Saltonstall) ("Our President, with the demands and almost inhuman burdens of his position, must have the people he wants close by to help him."); 99 CONG. REC. S465 (1953) (statement of Sen. Morse) ("[T]he President ... is entitled to have his official family consist of men in whom he has confidence and men whom [sic] he believes will carry out the policies which will characterize his administration.")

14. Several Democrats who crossed party lines to confirm John Ashcroft as Attorney General echoed such sentiments. Consider, for example, statements by Senators Feingold, Dodd, and Breaux:

This examination of the history [of cabinet appointments] demonstrates that it has been a nearly continuous custom of the Senate to confirm a President's nominees to the Cabinet in all but the very rarest of circumstances. These practices and precedents thus support the principle that the Senate owes the President substantial deference in the selection of the Cabinet.

147 Cong. REC. S981 (daily ed. Feb. 1, 2001) (statement of Sen. Feingold);

I do not expect that John Ashcroft will change his views [on many issues] as Attorney General .... I hope that [my vote] will be informative-informative most of all to John Ashcroft. Listen well, John Ashcroft. There are those of us today who could easily vote against your confirmation, but have decided to give you a second chance.

147 Cong. REC. S891-92 (daily ed. Jan. 31, 2001) (statement of Sen. Dodd);

I think all Presidents should have the opportunity to pick their own Cabinet. While I do not agree with the political philosophies of all the cabinet members, I believe it is the job of the Senate to reject a nomination only if the nominee is clearly unfit for the office.

Press Release, Senator John Breaux (Feb. 1, 2001) (on file with the Duke Law Journal). 
The Senate's recent confirmation of all of President George W. Bush's cabinet nominations confirms the durability of this deference. While the unprecedented 50-50 split in the Senate gave the President's party only the slimmest margin (with Vice President Cheney's tie-breaking vote), most of the President's nominees were confirmed without controversy. Only one nomination-that of John Ashcroft as Attorney General-was close. ${ }^{15}$ Generally, Democrats joined Republicans in overwhelmingly confirming his cabinet nominees. ${ }^{16}$

The first factor distinguishing subcabinet nominations from cabinet nominations is the percentage of nominations rejected. Although the percentage of subcabinet nominations rejected is lower than the percentage of cabinet nominations rejected, ${ }^{17}$ there are far more subcabinet posts than cabinet posts. Hence, more contests are possible over subcabinet than cabinet nominations. ${ }^{18}$

15. The Senate confirmed Ashcroft 58-42. Senate Roll Call on Ashcroft Vote, N.Y. TIMES, Feb. 2, 2001, at A16. Ashcroft's margin of victory was the narrowest for any Attorney General ever, including Edwin Meese III, who received 31 "no" votes in 1985. Alison Mitchell, Senate Confirms Ashcroft as Attorney General, 58-42, Closing a Five Week Battle, N.Y. TIMES, Feb. 2, 2001, at A1. The next closest vote was for Bush's nomination of Gale Norton as Interior Secretary, 75-24. Lizette Alvarez, Senate Confirms Nominees for E.P.A. and Interior Posts, N.Y. TIMES, Jan. 31, 2001, at A15. The other major contest over a Bush cabinet nominee involved Linda Chavez, who withdrew her nomination as Labor Secretary after questions arose about the propriety of her giving money to an illegal alien who lived with her and occasionally performed services for her and her family. Steven A. Holmes \& Frank Bruni, Chavez Cites Bush's Silence in Her Decision to Withdraw, N.Y. TIMES, Jan. 11, 2001, at A20.

16. The Senate confirmed President Bush's cabinet nominees in twelve days, a modern record. The speed and general ease of the confirmations are attributable to several factors, not the least of which was the decision by the Democratic Senate leadership to accept the legitimacy of Bush's presidency rather than turn confirmation proceedings into extensions of the postelection dispute between Bush and Gore. Not a single Democratic senator provoked a contest over any of Bush's cabinet nominees because of concerns about Bush's path to the presidency (at least not explicitly). In taking this tack, Senate Democrats refused to comply, at least as of the date of this publication, with strong public appeals that they block Bush nominees in retaliation for the illegitimacy of his presidency. For two such appeals from noted legal scholars, see Bruce Ackerman, The Court Packs Itself, AM. PROSPECT, Feb. 12, 2001, at 48 ("When sitting justices retire or die, the Senate should refuse to confirm any nominees offered up by President Bush.... Forty senators should simply make plain that they will block all Supreme Court nominations until the next presidential election."); Jack M. Balkin, Bush's Negative Mandate Narrows His Nominees, L.A. TIMES, Jan. 12, 2001, at B9 ("Under these circumstances, the Senate has the constitutional authority - and the duty — to hold [the President] to a moderate course. That is true of Cabinet appointments; it is even more true of judicial appointments that offer life tenure.").

17. Roughly at the mid-point of the Clinton administration, the Senate had turned down a mere 105 of more than 2.4 million executive nominations since 1932. Claude R. Marx, U.S. Officials to Be Named Later, INVESTOR's BUS. DAILY, May 13, 1997, at A1.

18. A study by the Twentieth Century Fund (now The Century Foundation) illustrates this point. The number of top-level executive branch positions (all requiring Senate confirmation) grew from 196 in the Kennedy administration to 786 in the Clinton administration. G. Calvin 
The second factor is the steady increase in party-line voting in Congress. ${ }^{19}$ Confirmation proceedings for subcabinet nominations are not immune from this phenomenon.

Indeed, an increased number of confirmation contests implicate a third factor. Confirmation skirmishes have tended to focus on nominations to offices in particular areas-civil rights, environmental protection, and national security-which deal with sensitive issues of significant interest to much of the public and special interest groups. ${ }^{20}$ This trend might reflect several attitudes among senators, including their recognition that certain nominations should be scrutinized more closely because presidents will have little regular contact with the nominees in question, who as a practical matter will have ultimate responsibility over politically sensitive subject matters. Thus far, President George W. Bush has maneuvered around this problem, with only one nomination to any of these offices - that of John Ashcroft as Attorney General—sparking a closely contested vote. ${ }^{21}$

MacKenzie, The Presidential Appointment Process: Historical Development, Contemporary Operations, Current Issues, in OBSTACLE COURSE: THE REPORT OF THE TWENTIETH CENTURY Fund TAsk Force on the Presidential Appointment Process 35, 42 tbl. 1.1 (1996). In 1993-1994, the Senate received over 77,000 presidential nominations (many of which were to military offices). Id. at 63 tbl. 2.2. The Senate rejected none of these nominations, but over 1000 of them were withdrawn. $I d$.

19. According to one study, from 1985 until 1993, the highest percentage of party-line votes in Congress in a given year was $13 \%$ in 1991 . GERHARDT, supra note 4 , at 168 . This same study indicated that from 1993 through 1999, the percentage of party-line votes ranged from 26 to $40 \%$. Id. These statistics reflect general legislative activity within Congress. My point is not that increases in party-line voting are unique to the confirmation process but rather that the latter process does not appear to be immune to the general phenomenon.

20. See id. at 168-72 (describing the trend over the past four decades toward contests in the Senate over nominations to offices with responsibility for civil rights, environmental protection, and national security).

21. Shortly before publication of this Essay, Theodore Olson, President Bush's nominee to be Solicitor General, faced tough questioning in his confirmation hearing before the Senate Judiciary Committee. Eric Lichtblau, Echoes of Ashcroft Heard at Solicitor General Hearing, L.A. TIMES, Apr. 6, 2001, at A24. Many Democratic senators were openly skeptical about his nomination because as a private citizen Olson had been a fiercely partisan critic of many policy initiatives of the Clinton administration, including many laws enacted during the preceding eight years. Id. Olson tried to deflect the harsh questioning by pledging to defend all federal laws, even those with which he vigorously disagreed. Id.; see infra note 60 and accompanying text. Olson is one of four top-level Justice Department nominees who had their nominations delayed as fallout from an intense partisan conflict over whether the Judiciary Committee will continue to allow one senator the privilege of defeating a nomination to a judgeship in his or her state by returning a "blue slip" in opposition to the nomination. Some senators wish to adopt a new practice requiring both senators from a state to submit blue slips in order to stop further proceedings on a judicial nomination in their state. Helen Dewar \& Thomas B. Edsall, Democrats Block Justice Picks; Senators Protest GOP Change in Judicial Vetting, WASH. POST, May 4, 2001, at A1; see infra notes 100-02 and accompanying text. 
Fourth, senators take special interest in nominations to federal offices in their respective states and also to leadership positions within institutions that are closely aligned with Congress, particularly commissions and agencies. Hence, presidents risk protracted confirmation contests with respect to such positions unless they negotiate with interested senators. ${ }^{22}$

The fifth factor influencing the frequency of contested subcabinet nominations is that Senate rules and traditions have made it easier for one or only a few senators to defeat such nominations without a full Senate vote. A longstanding, official rule of the Senate, ${ }^{23}$ in effect until earlier this year, ${ }^{24}$ required a majority of committee members to recommend a nomination formally before the nomination could reach the Senate floor for a final vote. While this rule never was invoked to prevent a cabinet nomination from reaching the Senate floor, it routinely was applied to impede subcabinet nominations, ${ }^{25}$

22. See Morton Rosenberg, Congress's Prerogative over Agencies and Agency Decisionmakers: The Rise and Demise of the Reagan Administration's Theory of the Unitary Executive, 57 GEO. WASH. L. REV. 627, 634 (1989) (describing and analyzing the proprietary interests that members of Congress have in the staffing and agendas of agencies and commissions). Particularly during President Clinton's second term, there were protracted contests over nominations to the Securities and Exchange, Federal Communications, Federal Election, and United States Sentencing Commissions. These contests ended only after the contending sides cut deals to achieve mutually satisfactory outcomes. See infra note 26.

23. Senate Rule XXVI provides in pertinent part, "[t]he vote of any committee to report a measure or matter shall require the concurrence of a majority of the members of the committee who are present." Senate Rule 26.7(a)(3).

24. For an example of the rare change in Senate rules approved in January 2001, see infra note 42 .

25. Enforcement of this rule has led to the defeat of many subcabinet nominations over the years. Perhaps the most notorious instance was the Judiciary Committee's split vote in 1997 over Clinton's nomination of Bill Lann Lee. See GERHARDT, supra note 4, at 170-71, 267-70 (describing the contest over and ultimate rejection of Lee's nomination because of a split vote on the Judiciary Committee that strictly followed party lines).

The fact that politicians understand that this rule will not be applied to cabinet nominees helps to explain the greater numbers of subcabinet nominees who withdraw their nominations. Nevertheless, it is noteworthy that within the last ten years, four cabinet nominees have been forced to withdraw their nominations: President Clinton's nominations of Zoe Baird and Kimba Wood as Attorney General and Bobby Inman as Defense Secretary and President George W. Bush's nomination of Linda Chavez as Labor Secretary. GERHARDT, supra note 4, at 166, 244, 247; Richard L. Berke, Bush's Transition Largely A Success, All Sides Suggest, N.Y. TimES, Jan. 28, 2001, at A1. The full significance of these forced withdrawals is not clear. A forced withdrawal is not the same as the formal rejection of a nominee because it does not require any formal action by the Senate. The people whose nominations have been withdrawn might have been confirmed, though no one will ever know for sure. Moreover, it is difficult if not impossible to prove precisely which nominations have been withdrawn. For instance, it is entirely conceivable that a forced withdrawal might not have occurred because of a significant loss of support in the Senate but because of other factors, such as the loss of confidence of a 
thereby allowing senators to defeat a nomination either by a negative vote from a majority of a committee or a tie vote in a committee. Moreover, nominations effectively can be nullified by committee chairs' refusals to schedule hearings or votes on the nominations in question, or by the Senate Majority Leader's refusal to schedule final floor debates or votes on pending nominations.

A sixth factor intensifying contests over subcabinet nominations is the amenability of subcabinet nominations to logrolling, or trading. One can imagine a vicious cycle emerging: (1) presidents are unlikely to invest much political capital in subcabinet nominations generally; (2) senators understand the small investments made by presidents in such nominations; (3) senators understand further that it might not take much to steer presidents into making the nominations senators prefer or conceding to senators on another point in exchange for nominating the president's first choice; and (4) presidents begin to resist cutting any deals over these nominations without getting something of value in return. ${ }^{26}$ High-profile contests over subcabinet nominations, which are rare, do not fit this pattern. These protracted contests involved nominations in which presidents felt invested personally or ideologically, and some senators were inclined to make presidents pay for their investment. Indeed, the few instances in which the Senate has rejected former or present Senate colleagues' nominations have arisen under precisely such circumstances. The Senate's rejection of Andrew Jackson's nominee Martin Van Buren as Ambassador to Great Britain ${ }^{27}$ and Harry Truman's nominee Mon

President in the nominee or a nominee's preference to save the President from the political or other fallout resulting from a bruising confirmation contest.

26. See, e.g., Tom Diener, Agreement Breaks Logjam on Clinton Appointees, PLAIN DEALER (Cleveland), May 24, 2000, at 10A (reporting an agreement reached between President Clinton and Senate leaders for Clinton's nomination of their preferred candidate to a seat on the Federal Election Commission in exchange for final Senate votes on sixteen of his judicial nominations); David E. Rovella, Sentencing Commission Returns to Business of Fair Justice, FULTON COUNTY DAILY REP., July 24, 2000 (reporting the consequences of a protracted contest between President Clinton and Senate leaders over naming commissioners of the U.S. Sentencing Commission); Senate Is Set to Vote on 16 Clinton Judicial Nominees, ST. LOUIS PosT DisPATCH, May 24, 2000, at A9 (reporting President Clinton's agreement to give Republican Senate leaders their preferred candidate on the Federal Election Commission in exchange for final votes on sixteen of his judicial nominations).

27. Joseph P. Harris, Advice And Consent of the Senate $55-57$ (1953). In 1831, President Jackson gave his Secretary of State Martin Van Buren a recess appointment as Minister to Great Britain as part of a scheme to reorganize his cabinet to reduce the influence of Vice President John Calhoun within his administration. Id. at 55. In January 1832, the Senate considered and rejected Van Buren's nomination, with Calhoun casting the decisive, tie-breaking vote against it. $I d$. at 57 . 
Wallgren as chairman of the National Security Resources Board, an agency charged with the critical task of planning the industrial mobilization of the country for national defense, were examples of this circumstance. ${ }^{28}$

\section{B. Norm Ambiguation and Beyond}

Norm ambiguation can create a context in which development of a new norm is possible. That is, new norms are more likely to develop when there is conflict over the meaning or status of an existing norm. ${ }^{29}$ Such conflict is evident in the recent uncertainty over whether sitting U.S. Attorneys should offer to resign to give newly elected presidents the chance to replace them. Before Bill Clinton's election, presidents expected that such resignations would be offered ${ }^{30}$ After Clinton's inauguration, several sitting U.S. Attorneys balked at offering to resign their posts once the Senate confirmed Janet Reno as President Clinton's Attorney General. ${ }^{31}$ After becoming Attorney General, Reno had made what she thought was the routine request that sitting U.S. Attorneys submit their resignations to her, so she could consider whether to reappoint them. She did not expect negative backlash because similar requests had been made by her predecessors in the Carter, Reagan, and Bush administrations and honored by previous U.S. Attorneys. Their refusals to tender their resignations embarrassed Reno, and, in fact, the desire to cause Reno embarrass-

28. Id. at 212. In 1948, President Truman's close friend and former colleague in the Senate, Mon Wallgren, lost his bid to be reelected as Governor of Washington. Id. A year later, the President nominated Wallgren as chair of the National Security Resources Board. Id. The nomination met stiff and ultimately fatal opposition in the Senate because most senators believed Wallgren's principal qualification for the job was that he was President Truman's close personal friend. Id. With only one deviation, the committee reviewing his nomination rejected it by a strict party-line vote, $7-6$, and the nomination died in committee. Id. at 213 . Subsequently, President Truman nominated Wallgren to the Federal Power Commission, and the Senate confirmed the nomination, 47-12. Id. at 214.

29. GERHARDT, supra note 4 , at 302 .

30. The one wrinkle appears to be that from Gerald Ford's presidency through George H.W. Bush's presidency, U.S. Attorneys in New York had been allowed to finish their four-year terms before offering to resign even if their terms extended into the term of a newly elected President. Andy Newman, White House Seeks Resignations of Three Prosecutors in New York, N.Y. TIMES, Mar. 16, 2001, at A1.

31. David Johnston, Attorney General Seeks Resignations from Prosecutors, N.Y. TIMES, Mar. 23, 1993, at A1. 
ment may have been the impetus for the refusals. ${ }^{32}$ After sending mixed signals on whether all sitting U.S. Attorneys should proffer their resignations to Attorney General Ashcroft, ${ }^{33}$ President George W. Bush and Attorney General Ashcroft requested the resignations of all but a few of the nation's U.S. Attorneys. ${ }^{34}$ Not a single Republican leader questioned the propriety of Bush's and Ashcroft's actions.

The absence of a governing norm, rather than conflict over its status, provides an even clearer invitation for actors to expand their authority. Beginning with Franklin D. Roosevelt, presidents have tended to expand the number ${ }^{35}$ and policymaking authority of White House staff members who are not subject to Senate confirmation. These expansions have given presidents a reliable process for reviewing policymaking efforts throughout their administrations. In fact, President George W. Bush consolidated within his White House staff the duties of evaluating possible judicial nominees ${ }^{36}$ and refining his administration's budgetary priorities. ${ }^{37}$

The true import of these recent trends is difficult to assess. A fundamental precondition of a norm is that its breach provoke sanction or retaliation. If neither of President Bush's recent actions-re-

32. See Lisa Hoffman, D'Amato Says Clinton Tried to Stack the Deck with Friendly Prosecutor, ARK. DEMOCRAT-GAZETTE, Mar. 18, 1994, at 14A (reporting that some observers agree that resignation requests are common when a new administration takes office).

33. See John Caher, Schumer Lobbying for U.S. Attorneys; Says Justice Department Not Seeking Resignations, N.Y. L.J., Feb. 27, 2001, at 1 (noting that at the time it was uncertain whether Clinton-appointed prosecutors would be asked to resign).

34. Newman, supra note 30 , at A1.

35. Two figures illustrate this point. First, President Nixon had only one lawyer serving as his official counsel, while President Clinton in his final year in office employed at least 19 fulltime lawyers in the White House Counsel's Office. At present, President Bush employs approximately a dozen full-time lawyers in the office. Second, the size of the White House staff assisting the President has grown from 53 in 1941 to 366 in 1990. JOHN P. BURKE, THE Institutional PResidency: ORganizing and Managing THE White House FROM FDR TO CLINTON 13 tbl. 1-1 (2d ed. 2000) (illustrating the change in the size of the White House staff from 1941 through 1990). In 1996, one analyst concluded that "[t]he most activist presidents have the largest staffs." 2 MiCHAEL NELSON, GuIDE TO THE PRESIDENCY 1086 (2d ed. 1996). Near the end of Clinton's presidency, there were 386 people listed on the White House staff.

36. See Neil A. Lewis, President Moves Quickly on Judgeships, N.Y. TIMES, Mar. 11, 2001, at A34 (noting President Bush's desire to make judicial appointments a priority of his administration and describing the system he put in place within the White House to facilitate and expedite judicial nominations).

37. President Bush has assembled a team of advisers from within the White House to review and resolve departmental appeals regarding his administration's budgetary priorities. Peter Grier, Cheney's Vice-Presidential Load Is Heaviest Yet, CHRISTIAN SCI. Monitor, Mar. 7, 2001, at USA, 1; Susan Page, Cheney Gives Up Ambition, Gains Power, USA TODAY, Mar. 5, 2001, at $1 \mathrm{~A}$. 
questing the resignation of U.S. Attorneys and expanding the size and authority of his White House staff-has triggered any sanction, then he probably has not violated a governing norm.

The difference between a practice that triggers sanctions and one that does not is the difference between a norm and a practice that is not, or perhaps is no longer, a norm. As will be discussed in the following section, this difference is crucial for political leaders to keep in mind when they are trying to maneuver through, or reform, the federal appointments process.

\section{REFORM AND NORMS}

This section considers ways norm theory can illuminate the amenability of the federal appointments process to reform. First, I discuss the structural impediments to formal alterations in the design of the federal appointments process. Second, I suggest how norms can be used to redress some major problems in judicial selection. Third, I sketch the requisite conditions for successful norm entrepreneurship in reforming the appointments process.

\section{A. Impediments to Formal Alterations}

Norms provide a useful perspective for analyzing the capacity of the federal appointments process for reform, because norms-unlike the formal structures and rules governing federal appointments-can sometimes be unstable. Presidents and senators rarely agree to any formal alterations in the structure of the appointments process unless they are convinced change is in their mutual institutional interests. The constitutional structure of the appointments process has never changed, and formal Senate rules governing confirmation proceedings have changed only rarely. Therefore, persuading presidents and senators to modify or abandon their prerogatives is difficult at best. ${ }^{38}$

The rarity and difficulty of formal structural or rule changes should not, however, mean that such change is impossible. Indeed, two changes within the last year signal national political leaders' willingness to reform the process when it is clearly in their mutual in-

38. Of course, incremental change may occur over time. See, e.g., GERHARDT, supra note 4, at 67-69 (discussing the evolution of the expectation regarding the personal appearances and testimony of judicial nominees before the Senate); $i d$. at 267-72 (discussing the Federal Vacancies Reform Act, enacted in 1998); id. at 275-78 (discussing civil service reform); id. at 321-24 (discussing the change in the Senate from closed to open hearings). 
terest to accomplish it. First, in the fall of 2000, Congress enacted the Presidential Transition Act of $2000,{ }^{39}$ which, inter alia, grants transition teams greater access to governmental information. Access to information should assist political appointees in acclimating to their new responsibilities prior to inauguration. In some ways, nominees' access to such information may serve to expedite their confirmation process. ${ }^{40}$ There is no hard evidence to explain why Congress streamlined the transition process shortly before the fall election. The timing of this reform raises, however, an inference that members of Congress from both parties might have agreed to the reform because they foresaw a tight election in which either candidate had an equal chance to win and, thus, to benefit from the new enactment's provisions.

A second change is more telling. The unprecedented 50-50 split in the Senate set the stage for Senate leaders to abandon the longstanding rule that a nomination could be forwarded to the full Senate for a final vote only if a majority of a Senate committee had formally recommended that it be forwarded. ${ }^{41}$ On January 5, 2001, Republicans agreed to allow equal representation of Democrats on all Senate committees in exchange for an agreement allowing the Majority Leader to schedule a floor vote on a nomination on which there has been a tie vote in committee. ${ }^{42}$ With this change, Democrats gained an

39. Presidential Transition Act of 2000, Pub. L. No. 106-293, 114 Stat. 1035 (amending Presidential Transition Act of 1963, 3 U.S.C. $\$ 120$ (1963)). The basic purpose of the Act was to streamline the transition phase and simplify the financial disclosure process for presidential appointees.

40. Neal Becton, Disclosure Reports Go Online at USDA; Forms Will Help Federal Appointees, WASH. POST, Jan. 2, 2001, at A13 (acknowledging that the primary purpose of the Presidential Transition Act was to "streamline the transition phase" by "simplify[ing] the financial disclosure" forms and requirements).

41. See supra notes 23-24 and accompanying text; infra note 42 and accompanying text.

42. Section 3 of the approved resolution provides,

If a committee has not reported out a legislative item or nomination because of a tie vote, then, after notice of such tie vote has been transmitted to the Senate by that committee and printed in the Record, the Majority Leader or the Minority Leader may, only after consultation with the Chairman and Ranking Member of the committee, make a motion to discharge such legislative item or nomination, and time for debate on such motion shall [take place] ... in order: Provided, That following the use or yielding back of time, a vote occur on the motion to discharge, without any intervening action, motion, or debate, and if agreed to it be placed immediately on the ... Executive Calendar (in the case of a nomination).

S. Res. 8, 107th Cong., 147 CONG. REC. S48 (daily ed. Jan. 5, 2001) (enacted). The Judiciary Committee's 9-9 vote on the nomination of Olson as Solicitor General, split strictly along party lines, provided the Senate leadership its first opportunity to take advantage of this rule change to bring a closely contested nomination to the floor of the Senate that would not have been pos- 
equal voice on every committee and Republicans prevented Democrats from using that equal voice to bar full Senate consideration of contested nominations. The bargain was a function of the relative numerical strengths of the two parties in the Senate.

\section{B. Institutional Norms and Reform}

In this subsection, I examine how existing norms can be used to address two major problems in the appointments process. These problems are (1) inordinate delays in processing judicial nominations and (2) inappropriate questioning of judicial nominees (including, but not limited to, an excessive focus on nominees' characters or, in the case of judicial nominees, on their judicial ideologies). ${ }^{43}$

1. Delays. Democrats complained about delays in processing judicial nominations throughout the Clinton presidency. By the end of the administration, two disturbing facts had become clear. First, the average numbers of days from the occurrence of a vacancy to a presidential nomination, as well as the average number of days from the nominations to final Senate action, were extraordinarily long. ${ }^{44}$

sible under the earlier set of rules. Neil A. Lewis, Senate Committee Is Split by Party on a Bush Nominee, N.Y. TIMES, May 18, 2001, at A1.

43. See generally StePhen L. CARTER, THE Confirmation Mess: Cleaning UP the Federal APPOINTMENTS PROCESS 117 (1994) (criticizing the litmus testing of judicial nominees). But see Michael J. Gerhardt, The Confirmation Mystery, 83 GEO. L.J. 395, 419-22 (1994) (review of STEPHEN L. CARTer, The Confirmation Mess: Cleaning uP THE Federal APPOINTMENTS PROCESS (1994)) (suggesting that probing judicial nominees' prospective ideologies is not a threat to their particular or to general judicial independence).

44. The length of the delays between the President's making nominations and the Senate's final actions on the nominations is striking for two reasons. First, the average number of days from the occurrence of a judicial vacancy to President Clinton's formal nomination to fill the vacancy was 536 days in 1998-99, 690 in 1994, and 753 in 1993, the latter two constituting the longest delays in American history. GERHARDT, supra note 4, at 124. The only other President with remotely similar delays was President George H.W. Bush in his first year in office, during which the average number of days from vacancy to nomination was 682. Id. at 125 .

The average number of days between nominations and final Senate action was 201 for the 105th Congress (1997-1998). Id. at 46 (indicating the average number of days between nomination and final Senate action during congressional terms from 1977 to 1998). In contrast, the average number of days between nomination and Senate final action in President Clinton's first year in office was 83. Id. During President Carter's four years in office, the average number of days between nomination and final Senate action ranged from 38 in the Ninety-fifth Congress (1977-1978) to 90 in the Ninety-sixth Congress (1979-80). Id. During President Reagan's eight years in office, the average number of days between nomination and final Senate action ranged from 32 in the Ninety-seventh Congress (1981-1982) to 144 in the 100th Congress (1987-1988). Id. During President George H.W. Bush's single term, the average number of days from nomi- 
Second, Clinton had failed to fill nearly one hundred judicial vacancies. $^{45}$

The first things to appreciate about this data are their causes. Divided government, an already unstable environment for norms, was further exacerbated by hard feelings between Republican congressional leaders and a President whom they impeached and tried to remove from office. ${ }^{46}$ Even so, the other cause was a norm-the traditional slow-down during presidential election years. ${ }^{47}$

With George W. Bush in the White House, the dynamic has been different. Republicans control the White House and the Senate for the first time since the first six years of Ronald Reagan's presidency. ${ }^{48}$ Moreover, President Bush has already demonstrated in his first few months in office how adhering to norms can help to secure desired

nation to final Senate action ranged from 78 in the 101st Congress (1989-1990) to 138 in the 102nd Congress (1991-1992). Id.

45. Lewis, supra note 36, at A34.

46. For a discussion of the extraordinary conflict between President Clinton and the congressional leadership culminating in and extending beyond his impeachment, see RICHARD A. Posner, AN AFFAIR OF STATE: THE INVESTIGATION, IMPEACHMENT, AND TRIAL OF PRESIDENT CLINTON 199-216 (1999) (describing the "culture wars" in which President Clinton was a "polarizing figure"); see also BENJAMIN GINSBURG \& MARTIN SHEFTER, POLITICS BY Other Means: Politicians, Prosecutors, and the Press from Watergate to WHITEWATER 25 (1999) (“[W]hen divided partisan control of government does coincide with sharp cleavages between the two parties, the importance of institutional conflict relative to electoral competition is likely to increase. This state of affairs has characterized American politics since the Vietnam and Watergate eras.").

47. See supra note 44 and accompanying text (indicating that the longest delays in the number of days between nominations and final Senate actions regarding them have been in presidential-election years for each of the past three presidents); see also Sheldon Goldman, Bush's Judicial Legacy: The Final Imprint, 76 JUdICATURE 282, 284 (1993) ("Traditionally, minimal confirmation activity occurs during presidential election years, especially when the Senate is controlled by one party and the White House by another.").

48. Indeed, Republicans control the White House and the Congress for the first time since Dwight Eisenhower's first term. Of course, the fact that the same party controls the White House and Congress hardly ensures a harmonious appointments process. A small but powerful contingent of Republican senators resisted and delayed (though failed to nullify) several of President Eisenhower's appointments (particularly his nominations to positions responsible for foreign policy and his nomination of Earl Warren as Chief Justice), see 2 STEPHEN E. Ambrose, EISENHOWER: THE President 56-61, 129 (1984), while President Hoover, during whose administration Republicans controlled both the White House and Congress, endured some notable confirmation contests, including the rejection of his Supreme Court nominee John J. Parker. See HARRIS, supra note 27, at 127-32 (describing the battle over Parker's nomination). Nor did the fact that Democrats controlled both institutions during Carter's presidency and the first two years of Clinton's presidency spare either of those men from numerous frustrating confirmation contests. The extent to which George W. Bush's record on appointments will be harmonious remains to be seen, though he and his staff have tried to learn from past presidents' (particularly Bush's father's) performances in office. Richard L. Berke, Bush Shapes His Presidency with Sharp Eye on Father's, N.Y. TIMES, Mar. 28, 2001, at A1. 
appointments. Particularly instructive are his adherence to three norms - senatorial courtesy, moderate political rhetoric, and advance planning for appointments. Senatorial courtesy is an especially durable norm. ${ }^{49}$ President Bush took advantage of it in successfully securing the appointments of three cabinet officers. ${ }^{50}$ Republican senators also expect Bush to defer to their suggested nominees for judicial vacancies in their respective states. ${ }^{51}$

When it comes to Supreme Court nominations, national political leaders expect the President to nominate sitting judges to the Court, a norm that has developed during the last two decades. ${ }^{52}$ Obviously, complying with the norm by nominating a sitting judge to the Court would increase the chance of a relatively smooth confirmation. This is especially true if the judge is someone who enjoys the backing of powerful or influential senators, as was the case with Justice Breyer. ${ }^{53}$ If presidents were looking for a relatively smooth or quick confirmation hearing for their Supreme Court nominee, then they would be well advised to deploy both of these norms in making a nomination: they would be wise to nominate a person who has been a sitting judge and who enjoys strong support among key senators.

49. See supra note 10 and accompanying text. It is noteworthy that John Tower is the only senator ever rejected as a cabinet nominee, while the Senate's rejection of President Grant's nomination of George Williams to the Supreme Court in 1873 was the last time the Senate rejected the nomination of a senator to the Court. See GERHARDT, supra note 4, at 115, 150 (discussing the Senate's rejection of Williams as President Grant's nominee to the Supreme Court).

50. The three cabinet officials are John Ashcroft (former Missouri senator) as Attorney General, Spencer Abraham (former Michigan senator) as Energy Secretary, and Norman Mineta (former representative) as Transportation Secretary. While Mineta's easy confirmation does not fit a narrow conception of senatorial courtesy because he was not a senator before being nominated and confirmed as President Clinton's last Secretary of Commerce, it is not unusual for representatives who are well known in the Senate to enjoy a similar degree of deference as senators in the confirmation process. GERHARDT, supra note 4, at 143-44, 147-48.

51. See infra note 87 and accompanying text.

52. See Henry J. Abraham, Justices, Presidents, and Senators: A History of SUPREME COURT APPOINTMENTS FROM WASHINGTON TO CLINTON 291-326 (1999) (describing Supreme Court nominations since President Reagan nominated Sandra Day O'Connor to the Court in 1982, the last time a person with substantial political experience was nominated to the Court).

53. See id. at 323 :

[O]n May 10, Clinton met with one of [Breyer's] most persistent advocates, Senator Ted Kennedy (D-Mass.) ... . Kennedy also assured Clinton that Breyer's close past warm connections as counsel with the Judiciary Committee would indubitably guarantee a quiet and bipartisanly successful confirmation hearing. Now sufficiently persuaded, and eager to fill the Blackmun vacancy without further delay, the president nominated [Breyer] .... 
If, however, presidents wanted to revive the lapsed norm of appointing political leaders to the Court, their best bet might be to take advantage of the likely deference senators would give to nominations of their congressional colleagues. The argument for nominating a current or former member of Congress is that her keen understanding of political institutions and policymaking will benefit the Court and the nation. Though such a nominee would bear the burden of persuading her colleagues that she appreciates the differences between legislating and judging, it might be easier for someone who is liked by most senators to win the opportunity to satisfy this burden than it would be for someone unknown to them.

The second norm followed by President George W. Bush to facilitate confirmation of his cabinet nominees is assembling a knowledgeable and competent staff to assist with transition matters (including recommending appointments) well before Election Day. ${ }^{54}$ Presidents who have followed this practice, such Reagan, have had relatively smooth transitions. For Bush, following the model culminated in a huge payoff-he had the quickest and smoothest confirmation of a cabinet in decades. His nominees all were confirmed within twelve days ${ }^{55}$ in contrast, President Kennedy's cabinet nominees required an average of 2.4 months to be confirmed, ${ }^{56}$ and Bill Clinton's nominees averaged 8.5 months to be confirmed. ${ }^{57}$

The third norm that President Bush followed to facilitate the smooth confirmation of his cabinet nominees relates to the "framing effect" of his rhetoric in characterizing his nominees. ${ }^{58}$ Characterizing nominees in modest terms has the effect of lowering expectations

54. See Berke, supra note 25, at A1 (describing in detail Bush's transition plans and models).

56. Editorial, A Cumbersome Process, Buffalo News, Apr. 13, 2001, at B16.

57. Id.

58. I refer to both President Bush's early planning for his transition and his employment of moderate rhetoric as compliance with certain institutional norms rather than strategies. Early planning is arguably an institutional norm that operates largely within the executive branch, particularly the Executive Office of the President. While no one within the executive branch has any formal power to sanction Bush for his failure to plan early for a transition, it is possible that his failure to do so might alienate some key administration insiders, who could retaliate by making damaging leaks or using their influence to impede appointments with which they disagree. The use of moderate rhetoric operates as a different institutional norm, which largely operates between the President and the Senate. It is possible to infer the existence of the latter norm from the costs imposed on presidents and their nominees when they fail to employ moderating rhetoric. 
about the merits of these nominees ${ }^{59}$ and of setting terms of debate that are conducive to confirmation. ${ }^{60}$ President Bush did not oversell his nominees. He told stories about their lives that made them appealing figures but did not raise expectations about their respective qualifications. ${ }^{61}$ In contrast, presidents who oversold the quality of some nominees have paid dearly for their exaggerations. ${ }^{62}$

2. Attacking Presidential Nominees. From the beginning of the republic to the present day, presidents have invariably considered

59. For a similar conclusion, see DAVID YALOF, PURSUIT OF JUSTICES: PrESIDENTIAL POLITICS AND THE SELECTION OF SUPREME COURT NOMINEES 168-70 (1999) (suggesting that presidents will act in certain ways, such as using moderate rhetoric, to preempt conflict with the Senate).

60. Just like President Bush, nominees can take advantage of the framing effect of their own moderate rhetoric in the confirmation process. Nominees can frame the terms of debate that facilitate their successful confirmations. Theodore Olson repeatedly pledged to the Senate Judiciary Committee that he would enforce and defend all federal laws, including those that he had personally opposed as unconstitutional prior to his nomination as President Bush's Solicitor General. Democrats Grill Pick for Solicitor General, SeAtTle Post-InTELligencer, Apr. 6 , 2001, at A3; Lichtblau, supra note 21, at A24. Through these pledges, Olson, Ashcroft, and Gale Norton pressured the opposition to debate their nominations in terms of the credibility of their pledges rather than the merits or appeal of their respective ideologies. The effectiveness of these pledges is evident from the fact that senators from both parties joined together to confirm Ashcroft and Norton. See supra note 15 and accompanying text. Olson's pledge did not, however, preclude his nomination from serious opposition on the Judiciary Committee. The Committee split evenly along party lines with Democrats voting against the nomination because of their concerns over the veracity of Olson's testimony about the degree of his involvement in certain anti-Clinton activities. Lewis, supra note 42, at A1.

Until this year, several Republican senators, none more aggressively than John Ashcroft, had opposed subcabinet nominees (such as Bill Lann Lee) even though they had pledged to defend all federal laws in spite of their personal doubts about their constitutionality. One could infer from such opposition the belief that subcabinet nominees' ideological views inevitably will guide their performances in office. The fact that Republican senators recently have urged the confirmation of nominees on the ground that their personal pledges to enforce all federal laws is much more relevant to their confirmation than their personal ideologies raises the interesting question of how these senators will treat Democratic nominees who make similar pledges in the future.

61. See Stephen Hess, The Presidency; Transition: Less Seems to Be More; It's Been a Good Month for Bush, L.A. Times, Feb. 25, 2001, at M1 (noting President Bush's reference to the "wonderful stories" many of his cabinet nominees' lives embodied). Similarly, nominees whose life stories made wonderful copy during their confirmation proceedings met with little resistance. See GERHARDT, supra note 4, at 184 (noting that Justice Scalia's status as the first Italian American nominated to the Supreme Court, Justice Thomas' rise from abject poverty, and Justice Ginsburg's status as the "Thurgood Marshall of the feminist movement" ultimately helped to secure each nominee's confirmation).

62. See, e.g., GERHARDT, supra note 4, at 127-28 (noting problems created by the unreasonably high expectations triggered by President George H.W. Bush's characterization of Clarence Thomas as the "best qualified" nominee for the Supreme Court and President Clinton's promise to have the most ethical administration in history). 
prospective nominees' likely judicial philosophies in making decisions about whom to nominate to the federal bench, and senators traditionally have viewed the confirmation process as the most significant political check on presidential judicial nominations. ${ }^{63}$ In exercising this check, senators generally viewed their core responsibility as determining the fitness of a judicial nominee, and they generally considered ideology as central to their evaluations of a judicial nominee's fitness.

President George W. Bush's Chief Counsel, Alberto Gonzalez, acknowledged the relevance of ideology in making judicial nominations. He noted that he and his staff ask prospective judicial nominees about their "philosophy." "We ask how they construe statutes, how do they resolve disputes and what do they believe is the appropriate role of judges." ${ }^{\prime 4}$ Gonzalez distinguishes such questioning from litmus tests-asking nominees questions that seek a direct answer to how they would vote on a given case, such as abortion-a practice he denies the White House is using. ${ }^{65}$ Both the distinction and the denial are disingenuous.

One longstanding norm within the executive branch is for presidents to choose judicial nominees based primarily on their judicial ideologies. Indeed, a prospective nominee's ideology will signal to those selecting possible nominees how the nominee likely would rule in a set or class of cases and, therefore, how the person would rule in any particular case. Having a set of questions designed to elicit information about likely ideologies is, then, nothing more than a test for filtering acceptable candidates from the pool of aspiring nominees. That is, the focus on ideology is itself a kind of litmus test, for it seeks to identify the prospective nominees with the "right" kind of ideology. Mr. Gonzalez no doubt appreciates that many senators will probe nominees about their likely ideologies. Some senators (particularly from the President's party) are likely to trust the judgment and representations of the White House regarding a particular nomination. Others who know that a President is having his prospective nominees screened for their ideologies likely will want to know and, indeed, claim the right to evaluate what those ideologies are. $\mathrm{Mr}$. Gonzalez disclosed that his staff engages in routine questioning of

63. Id. at $128-31,162-64$.

64. Lewis, supra note 36 , at A34.

65. Id. 
prospective judicial nominees about their likely ideologies. For many senators, this disclosure establishes the need to evaluate for themselves this information and how it should affect their determinations of nominees' fitness to serve. The dynamic in judicial selection thus becomes a vicious cycle in which a President makes decisions about whom to nominate based on information about their ideological preferences, and opposition party senators seek out the same information to determine why the nominations were made and whether they should be approved. ${ }^{66}$

If there is any problem with the search for a nominee's ideology, the problem is that the appointments process seems to reward distortions of nominees' records and characters for political and other gains. This problem is not unique to judicial selection, but it does arise in that context frequently because of the convergence of the basic norm of senators' granting little deference to judicial nominees and the framing effect of their condemnation of a nomination for purposes of influencing attitudes about it.

The Senate's rejection of Ronnie White's nomination to become a federal district judge in Missouri is a case in point. ${ }^{67}$ The rejection of White's nomination was the Senate's first rejection of a judicial nomination since Robert Bork's failed nomination as an Associate Justice in 1987. First, the event dramatically demonstrated the continued influence of political parties in the context of judicial selection. The final Senate vote on White was 55-45, which strictly followed party lines. Second, the rhetoric of White's opposition, led by then Missouri Senator John Ashcroft, was filled with hyperbole. In his confirmation hearings, White's opponents described him as "pro-criminal," "activist," and even as having a "tremendous bent toward criminal activity." 68

Third, White's rejection has had ramifications for Ashcroft and the Republican party to this day, particularly in the form of payback, or the propensity of senators to initiate confirmation fights in retalia-

66. There also is a temptation to imagine that there is some connection between judicial nominees' lifestyles or characters and their judicial philosophies. For a comprehensive critique of the inquiries into character driven by such thinking, see generally Laura Kalman, Does Character Affect Judicial Performance?, 71 U. COLO. L. REV. 1385 (2000).

67. For an overview and commentary on the fate of White's nomination, see generally Stuart Taylor, Jr., The Smearing of a Moderate Judge, CONN. LAW TRIB., Oct. 25, 1999.

68. Id. (quoting Senator Ashcroft's statements in opposition to White). 
tion for contests directed against their preferred nominees. ${ }^{69}$ Payback arguably has become a standard practice in the appointments process. Indeed, many Democratic senators already have used the Ashcroft confirmation hearings to signal to President Bush that they were not pleased with strongly ideological nominees such as Ashcroft and that they would oppose them if President Bush were to make any such nominations to the federal courts. ${ }^{70}$

Fourth, the aftermath of White's rejection illuminates the evolving norms of modern media coverage of political events. It is well documented that the media generally have been giving less coverage to hard news (which people use in performing their civic duties) and more coverage to soft news (which consists largely of speculation, commentary, and preoccupation with scandal). ${ }^{71}$ The more outlandish the claims made against a nominee or public official, the more likely they will get coverage. The fact that Ashcroft's treatment of White might have been "racist" drew media attention" away from his record on nonracial matters.

69. See, e.g., Stuart Taylor, Jr., A Character Assassin Should Not Be Attorney General, NAT'L J., Jan. 13, 2001, at 78 (arguing that Ashcroft's treatment of White should disqualify him from being confirmed as Attorney General).

70. See Mike Dorning, Senate Confirms Ashcroft, 58-42; Democrats Send Bush a Warning on Future Nominations, CHI. TRIB., Feb. 2, 2001, at A1 (quoting Democratic senators characterizing the sizeable vote against Ashcroft as "a shot across the bow" of the Bush administration); see also Paul Kane \& Mark Preston, Senate Judicial Battles Loom, Roll CALl, Mar. 19, 2001 (stating that key Democratic senators have indicated that they will not "roll over when it comes to President Bush's nominations to the federal bench"). Even though a central question in Ashcroft's confirmation hearings concerned the fairness of his treatment of White as a judicial nominee, Republicans voted for Ashcroft's nomination en masse. See, e.g., Dorning, supra, at A1 (describing the sources of Democrats' opposition to Ashcroft, including their criticisms of his treatment of Ronnie White). Only one Republican senator intimated that Ashcroft might have been unfair or mistaken in his assessment of White. See Mike Dorning, Judge Denounced by Ashcroft Speaks at Hearing, CHI. TRIB., Jan. 19, 2001, at A8 (describing Judge White's testimony during the Ashcroft confirmation hearings and Republican Senator Arlen Specter's acknowledgment of the possibility that White might not have received completely fair treatment in White's confirmation hearings).

71. See generally Robert McChesney, Rich Media, Poor Democracy (2000) (describing the transformation in media coverage from hard to soft news); Bill Kovach \& Tom Rosenstiel, Campaign Lite, WASH. MONTHLY, Jan. 1, 2001, at 31 (describing how over the past decade, and particularly during the 2000 election coverage, the press has turned more of its focus to personality, speculation, and commentary than to substantive issues); Marvin Kalb, The Rise of the "New News": A Case Study of Two Root Causes of the Modern Scandal Coverage 10-14 (Oct. 1998) (unpublished manuscript, on file with the Duke Law Journal).

72. See, e.g., Richard Lowry, "Conservative" and "Racist": The Ashcroft Nomination and the Left's Foulest Card, NAT'L REV., Feb. 5, 2001 (arguing that mere accusations of racism are potentially fatal, whether true or not, because of media attention and a general culture of "new racial McCarthyism"). 
Both White's rejection and its aftermath raise serious questions about the possibility of ever curbing distortions of records or character in Senate confirmation contests. If there is any solution to this problem, it could be in the realm of norms. First, there was at least one promising signal during the Ashcroft confirmation hearings that some senators are trying to curtail or contain the norm of payback. In casting his vote to confirm Ashcroft, Democrat Russ Feingold of Wisconsin explained that he intended his vote to be "an olive branch" to Republicans to end the vicious cycle of payback that had been undermining the appointments process. ${ }^{73}$ Senate Majority Leader Lott welcomed Feingold's gesture, and urged senators from both parties to follow Feingold's example. ${ }^{74}$

Second, Democrats made another important gesture toward limiting their urge for payback generated by confirmation hearings by refusing to allow or support a filibuster against Ashcroft. ${ }^{75}$ At least forty-one votes would have been needed to support a filibuster, ${ }^{76}$ and there were forty-two senators who voted against Ashcroft. Nevertheless, senators have never employed a filibuster on a cabinet nomination. The practice has been to employ filibusters only for judicial nominations, if at all $;{ }^{77}$ and the clear signals Democratic senators gave to President Bush on judicial nominations indicate they will be less hesitant to employ filibusters or other measures to block his judicial nominees than they were to use such means to block his cabinet nominees. $^{78}$

73. Alison Mitchell, By Resisting Ashcroft, Democrats Send a Signal, N.Y. TIMES, Jan. 31, 2001, at A14 (describing, inter alia, Senator Feingold's statement in support of Ashcroft's nomination).

74. See Craig Gilbert, Lott Hails Feingold's Gesture, MilwaUkeE J. Sentinel, Feb. 2, 2001, at A2 (quoting Senator Lott as saying, "[Feingold] showed courage . . . . [a]nd I won't forget it").

75. See Dorning, supra note 70, at A1 ("Only 41 senators are needed to stop a nomination through a filibuster, although Democratic leaders said they did not use the tactic against Ashcroft because some party members considered it inappropriate for a Cabinet nomination.").

76. See generally Catherine Fisk \& Erwin Chemerinsky, The Filibuster, 49 STAN. L. REV. 181 (1997) (summarizing the historical developments of Senate filibusters and evaluating the anti-majoritarian impact, if any, and the constitutionality of the modern filibuster).

77. See Kirk Victor, A Ticking Time Bomb in the Senate, 33 NAT'L J. 490, 490 (2001) ("Since 1968, Senators of both parties have waged overt filibusters against 13 judicial nominees, starting with Abe Fortas ....").

78. See Ann Gearan, Ideological Battle Set; Ashcroft Fight Sends Signal About High Court Nominees, South BEND TRIB., Jan. 28, 2001, at A3 (quoting Professor Susan Low Bloch of Georgetown as stating, "Normally the Senate is more deferential to a Cabinet appointment than to a life-tenured judicial appointment anyway, so if [the Ashcroft nomination] is very conten- 
Third, Democratic and Republican senators who are concerned about misrepresentations about nominees' records and characters can agree to adopt new norms for themselves and their staffs when it comes to attacking nominees. They could provide strict limits on the kinds of contacts they or their staffs will have with both the media and interest groups regarding prospective or pending nominations. Presidents could adopt similar measures by restricting their staffs from engaging in reckless or partisan leaks designed to hurt reputations of prospective nominees or foes.

Fourth, senatorial courtesy holds some promise for curbing the zeal of a nominee's opponents in distorting her record or character. To be sure, senatorial courtesy is not a panacea; it certainly has not prevented senators or interest groups from zealously opposing some of their colleagues' preferred judicial nominees. ${ }^{79}$ Yet, presidents often can foresee such opposition, as President Clinton surely should have foreseen the error of refusing to consult with either of Missouri's two Republican senators prior to nominating Justice White. It is safe to say such refusals are likely to exacerbate any tension or conflict that already exists between the President and Senate delegations over appointments matters.

The challenge for President Bush, who repeatedly promised to restore civility to political debate ${ }^{80}$ is to follow the successful practices developed for easing tensions in the appointments process. One obvious tack is to look for a consensus candidate, as President Clinton did with his two Supreme Court nominees. ${ }^{81}$ In addition, a President could agree to consult with both senators from the nominee's state when the senators are from different parties, to accept only suggested candidates who have the support of both senators, to nominate peo-

tious then it certainly signifies that a Supreme Court nomination will be that much more contentious").

79. Such zealous opposition helped to delay final Senate action on President Clinton's Ninth Circuit nominations of Marsha Berzon for two years and Richard Paez for four years. Kathleen Sullivan, S.F. Lawyer Finally a Judge, S.F. EXAMINER, Mar. 10, 2000, at A4. In 2000, the Senate confirmed the nominees, who had the strong support of the President and Senator Barbara Boxer. Id. Boxer's persistent support was an indispensable antidote to the opposition. See id. (describing how Boxer held up the confirmation of a Mississippi mayor to the Tennessee Valley Authority until action was taken on the confirmations of Berzon and Paez).

80. See, e.g., Ronald Brownstein, Bush Speech Attempt to Widen Support, South BEND TRIB., Jan. 21, 2001, at A3 (describing President George W. Bush's inaugural address and referring to Bush's promise to restore civility to Washington).

81. See GERHARDT, supra note 4, at 296 (describing President Clinton's Supreme Court nominees as "consensus candidates"). 
ple with good relations to key senators, or to have senators alternate in recommending nominations for judgeships in their respective states. ${ }^{82}$ Presumably, one issue for President Bush will be whether to continue (or expand) the prior practice of considering the recommendations of Senate delegations with at least one member from the opposition party. ${ }^{83}$ Thus far, Bush has not indicated his willingness to consult with such delegations, much less with the eighteen delegations in which both members are Democrats.

\section{Norm Entrepreneurs}

Creating new norms entails risking sanctions, because it often requires violating existing norms. Presidents Clinton and George W. Bush both made efforts to act as norms entrepreneurs, and their experiences illuminate both the risks involved and the likely explanations for their actions.

President Clinton acted as a norms entrepreneur when he made a recess appointment ${ }^{84}$ of a federal judge in the closing days of his administration. ${ }^{85}$ In doing so, he deviated from a norm of more than

82. See, e.g., Joel Connelly, Senate Confirms Gould's Court Appointment, SEATTLE PostINTELLIGENCER, Nov. 18, 1999, at C5 (discussing the agreement reached by Washington Senators Slade Gorton, a Republican, and Patty Murray, a Democrat, to join forces to make recommendations to the President concerning all vacant judgeships in their state); Josh Goldberg, About 30 Lawyers Apply for Federal Court Vacancy Here, CHI. Daily L. Bull., Apr. 7, 1999, at 1 (reporting Illinois Democratic Senator Richard Durbin's plans to consult with Illinois Republican Senator Peter Fitzgerald prior to making recommendations to the President on a nominee for filling a judicial vacancy in Illinois).

83. There are apparent limits to President Bush's professed desire to work with the opposition party in the appointments process: he quickly rejected the plea of some senators during the Ashcroft confirmation hearings that he consider renominating Missouri Supreme Court Justice Ronnie White to a federal judgeship. Bush Won't Nominate Black Missouri Judge, SEATTLE Post-InTElligencer, Feb. 3, 2001, at A3. Similarly, President Bush's decision to abandon consultation with the American Bar Association further indicates his resistance to taking any unusual steps in building bridges with at least one mainstream organization with strong ties to both parties. Moreover, President Bush indicated to Washington state's two Democratic senators that they would have no special say in recommending candidates for judicial nominations; instead, his Counsel directed that the only avenue by which they could seek some say in the administration's judicial nominations was through negotiation with Jennifer Dunn, a Republican representative, whom the administration designated as its "appoint-person" on nominations to federal judgeships in the state of Washington. Les Blumenthal, White House Puts Rep. Dunn in Driver's Seat for Screening Bench Nominees, NEwS TRIB., Apr. 8, 2001, at B7.

84. U.S. CONST. art. II, § 2, cl. 3 ("The President shall have Power to fill up all Vacancies that may happen during the Recess of the Senate, by granting Commissions which shall expire at the End of their next Session.").

85. The constitutionality of recess appointments of federal judges is unclear. On the one hand, Article III provides that judges, both of the Supreme and lower federal courts, shall hold their offices during good behavior, a phrase commonly construed to mean they serve for life 
twenty years in which presidents did not make recess appointments of federal judges. ${ }^{86}$ The deviation was a response to North Carolina Senator Jesse Helms's efforts for more than six years to put holds on judicial nominations and thereby thwart every one of President Clinton's nominees-all African Americans-to a North Carolina seat on the U.S. Court of Appeals for the Fourth Circuit. ${ }^{87}$ To maneuver around Helms's assertion of privilege, Clinton nominated an African-American lawyer from a different state in the Fourth CircuitRoger Gregory from Virginia-to fill the seat initially reserved for a North Carolinian. In late December 2000, President Clinton named Gregory as a recess appointment to the Fourth Circuit. ${ }^{88}$

The recess appointment initially put the onus on the Senate to reject Gregory's nomination and, thereby, risk alienating African American voters. By late January, both of Virginia's Republican senators endorsed Gregory and asked President Bush to nominate him for a permanent slot on the Fourth Circuit. ${ }^{89}$ With both of Virginia's Republican senators on record as supporting Gregory, there was enormous pressure on President George W. Bush to renew the nomination, particularly in light of Senator Warner's warning that "[w]hen two senators take the initiative as we have done, despite the

unless they are removed for having committed an impeachable offense. Federal judges who have been appointed by means of a recess appointment do not serve for life but instead are prone to political retaliation, because they serve only until the end of the next congressional session, unless they are re-nominated by the President and confirmed by the Senate. On the other hand, the clause of the Constitution empowering the President to make recess appointments provides in clear language that he is entitled to fill all vacancies that may occur during the recess of the Senate. The apparent tension in these readings can be resolved to some extent by recognizing that Article III power may be exercised by judges who are appointed in compliance with either the Appointments Clause or the Recess Appointments Clause.

86. Editorial, Roger Gregory, Political Prop, WASH. TIMES, Dec. 20, 2000, at A18.

87. See Lyle Denniston, Politics, Race Cloud Naming of Judges to U.S. 4th Circuit; Clinton Ducks Senate to Appoint First Black, BALT. SUN, Jan. 8, 2001, at 1A (recounting the objections of Senator Helms to each of Clinton's previous appointees to seats on the Fourth Circuit in North Carolina based on the belief that the court does not need any additional judges). Although one of Senator Helms's reasons for blocking President Clinton's nominations to Fourth Circuit seats in North Carolina was to retaliate against the Democrats' blocking of President George H.W. Bush's nomination of Terence Boyle to the Fourth Circuit, President George W. Bush has signaled that Boyle will be included among his first batch of judicial nominees as a nominee to a seat on the Fourth Circuit. Peter Hardin, Gregory Posting Is Called Closer, RICHMOND TIMES-DisPATCH, May 4, 2001, at A1.

88. Brooke A. Masters \& Spencer S. Hsu, Allen, Warner Endorse Gregory; GOP Lawmakers to Fight for Judge, WASH. POST, Jan. 26, 2001, at B9.

89. Id. In fact, in his first floor speech as Virginia's newly elected Senator, Republican George Allen urged President-elect Bush to re-nominate Judge Gregory for a permanent seat on the Fourth Circuit. Id. 
unusual nominating process, I am confident the president will accede to our wishes. ${ }^{, 0}$ In May 2001, word leaked from the White House that President Bush intended to nominate Gregory to the Fourth Circuit. ${ }^{91}$ If the nomination is made and confirmed, President Clinton will have succeeded in refashioning the President's authority to use recess appointments to resolve impasses in the judicial selection process. ${ }^{92}$

In contrast, President Bush wasted little time after becoming President to act as a norms entrepreneur by jettisoning the longstanding norm of allowing the American Bar Association (ABA) to re-screen possible judicial nominees. ${ }^{93}$ Beginning in 1946 and extending through the first two years of the Clinton administration, Senate leaders routinely requested and received formal ratings from the

90. $I d$.

91. Hardin, supra note 87, at A1. On March 19, 2001, President George W. Bush had formally withdrawn Gregory's nomination to the Fourth Circuit. Peter Hardin, Bush Rescinds Offer to Gregory; Remains Eligible for Federal Bench, Richmond TIMEs-DisPATCH, Mar. 20, 2001, at A1. President Bush's spokesperson explained that his withdrawal of Gregory's nomination, along with over sixty others made by President Clinton, was intended to give the President a chance to make his own decisions on whom to nominate. Id.

92. Another controversy over Clinton's recess appointments involved Senator James Inhofe's repeated efforts to put holds on all pending judicial nominations to retaliate against what he perceived as President Clinton's breach of the norm governing recess appointments-a norm he believed required Clinton to give all senators advance notice of the names of all persons the President intended to designate during the next recess as recess appointees. See Lott Persuades GOP in Senate to Allow Two Judges' Confirmation, ST. Louis Post-DisPatch, Feb. 11, 2000, at A10 ("Inhofe, R-Okla., accused President Bill Clinton of violating an agreement on making temporary recess appointments, a method of bypassing the Senate confirmation process."). Senator Majority Leader Lott eventually cut deals with Clinton to comply with the norm and Minority Leader Daschle to guarantee final votes on most of the pending nominations. Id. (describing Lott's efforts to get Senate confirmation for Thomas Ambro and Joel Pisano).

93. Another recent example of a norm entrepreneur is J. Harvie Wilkinson, the Chief Judge of the Fourth Circuit. Judge Wilkinson not only testified before the Senate in support of a bill to abolish the seat to which Gregory had been nominated, but also went on national television to explain his opposition to filling the seat. The NewsHour with Jim Lehrer (PBS television broadcast, Jan. 5, 2000) (Transcript \#6635) (on file with the Duke Law Journal). His interview violated the norm that sitting judges generally make comments on prospective or pending judicial nominations only in private or through official channels. The norm from which Judge Wilkinson deviated presumably exists to fill the gaps left by statutes and judicial canons to guide federal judges on issues that clearly implicate judicial selection. It is difficult to maintain, as Judge Wilkinson did, that his sole concern was with "judicial administration," because there were pending nominations to each of the seats Judge Wilkinson agreed should have been abolished, and there had been prolonged contests between the President and Senator Helms to fill those seats. Under such circumstances, one wonders not only about the risks Judge Wilkinson undertook in deviating from the prevailing norm but also what impact those risks might have on his future judicial career. The answer will shed some light on the relative robustness of the norm regarding judicial involvement in judicial selection matters and whether Judge Wilkinson's deviation signals the evolution of a new norm. 
ABA on all judicial nominations. ${ }^{94}$ Ever since the ABA gave a mixed rating to Robert Bork in his confirmation hearings, many Republicans have doubted the organization's claim that its ratings are based on professional credentials and not to some extent on the ideology of judicial nominees. ${ }^{95}$ In 1997, Senator Orrin Hatch, the Chairman of the Senate Judiciary Committee, concluded that these doubts had sufficient merit to justify doing away with the ABA's privileged status in testifying for or against judicial nominations.

In spite of this edict, President Clinton continued to consult informally with the ABA prior to making his judicial nominations. ${ }^{97}$ In March 2001, President Bush's Chief Counsel signaled Bush's plan to end the practice of giving the ABA privileged status in rating judicial nominees. ${ }^{98}$ Ending the practice likely will remove one obstacle to Bush's desired judicial appointments. ${ }^{99}$ His ultimate success in this endeavor depends on whether it will cause delays while the Democrats consult with the ABA in the confirmation phase and on whether it consolidates the core political support Bush deems necessary.

Republican senators on the Judiciary Committee also recently tried to act as norms entrepreneurs by trying to change the Committee's practice regarding "blue slips." While Chairman of the Judiciary Committee during Clinton's presidency, Senator Hatch allowed a judicial nomination to be permanently stalled if a single Republican senator from the state to which the nomination was made returned a blue slip signaling his or her opposition to the nominee. ${ }^{100}$ When Senator Hatch indicated he did not intend to allow the same practice at the outset of Bush's presidency, Democrats on the Committee threat-

94. See SHeldon Goldman, Picking Federal Judges: LOWER COURT SElection FROM ROOSEVELT THROUGH REAGAN 86-88 (1997) (discussing the ABA's rating of Truman's judicial nominees); id. at 120-23 (discussing the ABA's rating of Eisenhower's judicial nominees); $i d$. at 167-87 (discussing the ABA's rating of Kennedy's judicial nominees); id. at 210-25 (discussing the ABA's rating of Nixon's and Ford's judicial nominees); id. at 263-74 (discussing the ABA's rating of Carter's judicial nominees); id. at 295-96, 309-35 (discussing the ABA's rating of Reagan's judicial nominees); Neil A. Lewis \& David Johnston, Bush Would Sever Law Group's Role in Screening Judges, N.Y. TIMES, Mar. 16, 2001, at A1 (suggesting, inter alia, Clinton's retention of the ABA's role in screening or rating prospective judicial nominees).

95. Amy Goldstein, Bush Set to Curb ABA's Role in Court Appointments, WASH. Post, Mar. 18, 2001, at A2.

96. GERHARDT, supra note 4 , at 230 .

97. Lewis \& Johnston, supra note 94, at A1.

98. Id.

99. Id.

100. Dewar \& Edsall, supra note 21, at A1. 
ened to filibuster all of Bush's judicial nominations and block any Committee vote on pending Justice Department nominations until they could work out a mutually satisfactory arrangement regarding blue slips. ${ }^{101}$ Democrats subsequently modified their strategy to allow a unanimous vote on Bush's nominee for Deputy Attorney General but otherwise to use pending Justice Department or judicial nominations as bargaining chips in negotiations over blue slip policy. ${ }^{102}$ Once President Bush formally made his first set of eleven judicial nominations, he included at least one on which the home-state senators might disagree, precipitating further power-plays by Senator Hatch and Democrats over scheduling and possible delays of confirmation hearings for the initial group of nominees. ${ }^{103}$ Republican senators' ultimate success as norms entrepreneurs depends on avoiding filibusters and maintaining their control of the Senate.

\section{CONCLUSION}

In this Essay, I have sketched the relevance of norm theory to the federal appointments process. Norms such as senatorial courtesy apply differently to different political appointments, and apply with different intensity and to different degrees, depending on such factors as the relative numbers of offices to which nominations are made, the tenure and scope of responsibility of the offices in question, the relative ease of defeating certain appointments in committee, and the relative robustness and certainty of the applicable norms. Norm theory illuminates ways national political leaders can act within the appointments process as entrepreneurs, but suggests that they must risk sanctions for violating existing norms. The recent actions of Presidents Clinton and Bush and leading Republicans as norms entrepreneurs-Clinton in his recess appointment of Roger Gregory to the Fourth Circuit, Bush in barring the ABA from having any privileged status in rating judicial nominees, and Republican senators in trying to revise the use of blue slips-illustrate the risks and possible pay-

101. Id.

102. See Douglas Turner, Schumer Balks over Bush Court Nominees, BUFF. NEWS, May 10, 2001, at A1 (quoting Democratic Senator Charles Schumer's description of how the White House must meet Democrats in its selection of judges).

103. See Lee Davidson, Hatch Threatens Tit-for-Tat Tactic, DESERET News, May 12, 2001, at A1 (describing partisan feuds over several nominees); Turner, supra note 102, at A1 (identifying nominees who are potential targets for Democratic opposition). 
offs. The risks and possible payoffs are the same in all three cases: alienating senators from the opposing party in an effort to preserve or expand the norm entrepreneurs' respective appointments authority.

It is too early to tell whether these leaders' actions have been fruitful. It is not, however, too early to assess what their actions tell us about the relevance of norms to reform of the appointments process. Their actions are reminders that the driving force of this system is the informal rules developed by the very parties the rules need to constrain. These rules are not immutable. Appreciating their nature and the political risks of noncompliance are crucial for anyone interested in charting a successful path through the federal appointments process. 